\title{
Adenoid Cystic Carcinoma
}

National Cancer Institute

\section{Source}

National Cancer Institute. Adenoid Cystic Carcinoma. NCI Thesaurus. Code C2970.

A malignant tumor arising from the epithelial cells. Microscopically, the neoplastic epithelial cells form cylindrical spatial configurations (cribriform or classic type of adenoid cystic carcinoma), cordlike structures (tubular type of adenoid cystic carcinoma), or solid structures (basaloid variant of adenoid cystic carcinoma). Adenoid cystic carcinomas mostly occur in the salivary glands. Other primary sites of involvement include the lacrimal gland, the larynx, and the lungs. Adenoid cystic carcinomas spread along nerve sheaths, resulting in severe pain, and they tend to recur. Lymph node metastases are unusual; hematogenous tumor spread is characteristic. 